ISSN 1392-0340 (Print)

ISSN 2029-0551 (Online)

https://doi.org/10.15823/p.2019.135.12

Pedagogika / Pedagogy

2019, t. 135, Nr. 3, p. 217-239 / Vol. 135, No. 3, pp. 217-239, 2019

VYTAUTO DIDŽIOJO

UNIVERSITETO

ŠVIETIMO

AKADEMIJA

\title{
Distance Professional Training of Undergraduate Economics Students in Russia
}

\author{
Miliausha Faritovna Sirazetdinova ${ }^{1}$, Rushana Khusainovna Lukmanova ${ }^{2}$, \\ Anatoliy Igorevich Stoletov ${ }^{3}$
}

1 Bashkir State University, Institute of History and Public Administration, Scientific and Organizational Department, 1 Tukaev St. (entrance from Karl Marx St. 3/4), Building I, Office 501, 450076 Ufa, Russia

2 Bashkir State University, Institute of History and Public Administration, Department of Foreign History, 1 Tukaev St. (entrance from Karl Marx St. 3/4), Building I, Office 519, 450076 Ufa, Russia

3 Bashkir State Agrarian University, Faculty of Agricultural Technologies and Forestry, Department of SocioEconomic Disciplines and Humanities, 3450 let Oktyabrya St., Office 356/1, 450015 Ufa, Russia

\begin{abstract}
The research aims to identify the positive and negative experience of application distance learning for Economics students in Russia. Unlike most papers studying the motivation of applicants to choose economic distance education, the paper discusses the factors of its development in Russia, which differs both from those in the US and Europe, and from other specialties in Russia. The explanatory material is the statistics of admissions ratesand the analysis of universities' location.
\end{abstract}

Keywords: e-learning, electronic educational environment, professional training, educational standards, MOOC (Massive Open Online Courses), distance learning systems (DLS).

\section{Introduction}

Distance training is widely used in North and Latin America and Europe, but it is rather new to Russian higher education system, whichis experiencing the most intensive period of e-education development, although there are "very few teaching methods and materials capable of creating a holistic picture of the subject and controlling the assimilation of the curriculum" (Martyanova, 2012), and lack of teachers working in this format. This is still true in 2018, according to the present research. In 2016, the distance 
segment (number of students) in Russia reached 3.7\%; but according to the forecast, by 2021 it will grow to nine percent (Ed Market research, 2017, 144). According to "Higher School of Economics” National Research University (HSE, 2017a), Russian e-learning market has already become the fastest growing in the world due to start-ups and private educational portals.

However, it remains unknown whether it will have the same features that it has in the West. This research evaluates the reasons for the differences in e-learning application and their impact on the effectiveness of e-learning. It is useful to consider the experience of Russian HEIs in ensuring the accessibility and quality of educational services using e-learning, in particular, in training of Economics students, the largest part of overall distance students number. Over almost three past decades after the USSR collapse, there has been a large increase in the number of HEIs that offer Economics programs, as well as in the number of students enrolling in these courses (HSE, 2017c).

Recent studies in Russia have focused on the extent to which DLS is applicable in Russian higher education, often without reference to the specialty, and assessed it as reducing the quality of education (Markova et al. 2017, 689).

In this paper, we did not compare the effectiveness of Economics students in e-learning courses and those engaged in classrooms. However, judging by the requests from the forums, most likely, introductory and first lessons in the first year should be conducted in the classroom, gradually increasing the proportion of the blended and fully distance classes. Another way considered by researchers is blended learning widely practiced abroad, where already by 2003, eighty percent of all universities and $93 \%$ of $\mathrm{PhD}$ students offered hybrid or blended learning courses of Economics Program (Cosgrove \& Olitsky, 2015), and in Russia - more often in police colleges.

Pedagogical issues of teaching Economics to e-students remain insufficiently developed. The exceptions are studies on practical application of Moodle at Dagestan State Institute of National Economy, International Eurasian University, Institute of Social and Humanitarian Knowledge in Kazan, University of Economics in Bratislava (Kerimbaev et al., 2017) and on organization of e-learning of mathematical disciplines for engineering students in Moodle (Zykova et al., 2017).

Recent studies have examined assessments, achievements and graduation courses or exclusions, often within one or more universities without taking into account the features of DLS used. Several studies compared test scores for Economics and Navy sailor students in online and face-to-face sections of an Economics course, introductory Microeconomics course, statistics classes, show that overall student performance is weaker in online courses, and that e-learning is associated with lower grades (Bosshardt \& Chiang, 2018; Bacolod et al., 2018, 1131, 1139).

Exceptions are studies of Blackboard and Aplia impacton the behavior, impressions, and success of Principles of Microeconomics course (Horspool \& Lange, 2015); the progress in e-courses in Economics of Calafiore and Damianov (2011) depending on 
the time spent by students on the Blackboard, and of Caviglia-Harris (2016) for video lectures from Khan Academy. Conclusions usually depend on the effectiveness of any online learning. American researchers analyzed nine of the most popular open platforms for DLS including Atutor, Dokeos, Moodle, and Sakai.

The criteria were grouped into eight modules: i) management tools for the training course, ii) administrative capabilities, iii) technical aspects, iv) adaptability, v) ease of platform application, vi) user data management, vii) learning facilities, and viii) communication tools (Guri-Rosenblit, 2005).

We still have not found the papers showing this by examples of the merits and demerits of e-platforms, which differ from each other. It is questionable whether different educational organizations using similar online platforms experience similar challenges, and whether the extent to which these educational online platforms are similar and that their advantages and disadvantages are the same.

There is voluminous literature that analysespersonal socioeconomic status and motivation as the major determinants of choice of e-learning. However, the objective sociocultural or economic and historical factorscontributing to the high demand and relatively low quality for e-educationin the particular case if Russia is not well understood. Although there is literature on the effectiveness and assessment of Economics online education, recent studies do not content satisfactory information on organizational, pedagogical, and technological parameters affecting its quality. This paper addresses this gap through a review of online platforms together with the feedbacks and reflecting on Russiantwo decades' experience of using e-learning tools and experiments and its official legalization. This appears to be relevant to both policy and research and could help administratorsand business representatives to better understand and develop a type of a guide for further improvement of both e-learning and labor markets. International practitioners can learn about issues and expectations of Russian e-students, who could apply for foreign universities in future, and about the overall situation with the e-education quality in Russia, for instance, when Russian specialists apply for the jobs abroad.

We investigate the difference in motivation and the underlying social and economic processes that guide it. For example, in the US, distant economic education is more often chosen by those who are looking for higher schedule flexibility, and less often by "non-traditional students with family responsibilities or off-campus employment"(Horspool \& Lange, 2015). In Russia, the contingent of e-students is made up of individuals from the age of 19 years old, combining their work and studies (88.9\%), having full-time jobs (85\%), marking one of the three reasons for choosing to be able to combine their work and study (72\%). They choose to get an education at the place of residence (58.6\%); schedule flexibility (26.1\%) and reasonable tuition fees (24.7\%) (Markova et al., 2017).

However, it seems that the necessity of working from the age of 19 , when a person does not yet have the first higher education, already indicates the importance of fees. Therefore, it is necessary to identify the objective factors of choice, one of which is a fee 
not clearly allocated by the respondents. Our hypothesis is due to the fees for full-time higher education for a student in Moscow or a major regional center form from not only the learning fees, but also the costs of living, food, medical and consumer services. Unlike in other countries, the annual income of a person with higher education in Russia is not much higher than that of a person without a diploma. DLS does not have indirect costs, such as the late start of a career, leaving the place of residence, loss of familiar comfortable environment and acquaintances affecting the recruiting.

The research questionsaddressed are the following. Why does a Russian student of Economics choose distance education? What are the positive and negative aspects of virtual interaction in the educational environment when receiving the economic education, and what is a relation between technical, material, pedagogical and organizational problems and the specifics of Russian distance Economics education? What are the basic innovative and pedagogical directions and conditions for Economics courses and disciplines, and how to increase the effectiveness of distance educational technologies in the national education system in Russian universities?

This research focuses on the question - why distance Economics education in Russian HEIs is a choice for many students regardless of its shortages, which are also studied in the paper. The hypothesis that unique Post-Soviet economy conditions - financial, infrastructural, legal, territorial and climatic causes its delayed but rapid development due to high demand. The hypothesis is tested by collecting data on the number of distance Economics students in comparison to other commercial students; assessing open-accessed Russian DLSs and global platforms applied at Russian Universities as well as comments in their databases, on the advantages and the shortcomings (determined by the content and the technical convenience of DLS application). The sample consisted of 56 universities delivering distance Economics programs.

The paper is organized as follows. The research background provides a brief overview of the unique conditions of e-learning development in Russia. In the following, we begin by discussing the conceptual framework used to organize the study and explain the material, the data collection, and the methodology. The first results' subsection reviews relations between factors of choice, growth and challenges of economic distance learning in Russia. The next subsection discusses in more details the specific features of DLS application, compares the relative strengths and weaknesses of using e-learning platforms or MOOCs. In Discussion, the lessons that researchers, educational policy-makers and practitioners can learn from the findings are assessed. The final section provides conclusions and avenues for further research on Russian e-education system. 


\section{Research background}

This paper is not the first to deal with the issues of Russian distance education, including Economics courses. To the best of our knowledge, although, it is the first to make the claim that they have a unique background - a set of historical political, economic, and technical factors that hindered its development, as well as objective geographic and climatic conditions behind a huge demand and potential benefits of implementing e-education particularly in Russia. The Russian market of distance education in 2016 has become the most evolving market of e-learning in the world, although it is only at the stage of formation, becoming clearly regulated only in 2012 .

Although universities initially had little confidence in DLS during the experimental period of 1997-1999, the corporations Rusal, Basic Element Holding, Sibneft, Vympelkom began active use of DLS (custom or in-house development) for their employees. American e-platform Aplia also originally developed for courses in Economics (Aljamal et al., 2015, 38). E-education of economists has an origin in Russian business corporations and pilot implementation of DLS by pioneer universities even before 2000 .

Given this, it is surprising that e-learning has notbeen widely used and are still underdeveloped. Some factors discussed further might deter universities from applying them. Online learning began to spread back in the 1990s, and in 1995, about one-third of the four-year institutions of higher education in the US offered online courses (Lewis et al., 1997, 6). In Russia, DLS development is delayed due to the later information in comparison with Western Europe and the US, although "computer use is not well integrated into teaching and learning" yet (Hauge, 2014, 311).

The establishment of Internet centers (about 2000) preceded the introduction of distance education in most Russian universities. By 2005, e-catalogs of libraries appeared, then e-libraries appeared along with the opening of access to all-Russian electronic libraries and international scientific databases information, as well as the mandatory placement of the search tool, educational and other documents, on the sites of the universities (after 2010). Only in November 2011, the Information Technologies Center of the Tupolev Kazan National Research University (KNITUKAI, 2018) organized e-learning for staffs of universities. MESI (Moscow State University of Economics, Statistics, and Informatics), joined to Plekhanov Russian University of Economics (RUE), having foreign branches, was one of the first to introduce Management, Economics, Jurisprudence higher education online programs.

Since February 2012, online education and DLS have been legalized as an official form of education, and the diploma of higher distance education is equated to full-time, part-time and evening diplomas issued (Federal Law No. 273-FZ). E-learning in most specialties makes only the first steps after legislation and because of applicants' inability to pay expensive full-time education in the reduction of state-financed openings. The appropriate processing of educational standards took time after the law came into force. 
The main users of educational services including DLS are the young generation from 18 to 35 years old, formed during the computerization.

In September 2015, the National Platform for Open Education designed for more than ten million students appeared by the joint efforts of eight leading universities and designed to compete with the renowned Western e-platforms. Only in 2016, well-known projects associated with free courses and claiming to reach a large audience began to gather speed. Until now, few Russian projects are providing free access to quality courses.

Reading the news on the official websites of universities, we found that the introduction of multi-stage examinations of online courses is taking place not only by the One Window Current Digital Educational Environment Federal Portal since the very moment of the opening of this project, but also by universities that value their own reputation.

KNITU-KAI (2017) added the expertise for distance education programs after unsightly facts of formal, irresponsible attitude towards the examination by some authors of e-courses (inconvenience, lack of access rights, copying other lecturers' courses received positive expert opinion, the exchange of courses by teachers replacing only the name of the author, and representing them to the examination as new ones). An expert commission, signing the expert opinion while never accessed the course. In case of non-compliance with the requirements, an expert records a video and a text file with the recommendations for correction and noting the strengths, which is visible only for the author. The expert does not close the revision process until the author eliminates shortcomings. This requires a study of the shortcomings of the Russian HEIs' DLS use including the difficulties encountered by students and teachers.

One can see from above that e-learning history in Russia had begun with the rise of commercialfirms and within non-state (private) universities, primarily offering Economics courses, and resulted in the rapid implementation after the rise of paid education. This may suggest that thebusiness-oriented approach strongly affected the acceptance of e-education format and will affect its efficiency and wide-spreading.

\section{Materials and Methods}

In order to answer to the research questions, unlike previous studies, we analysed not the outcomes of online learning in the form of academic progress or the achievements of a certain class of one university, but looked at the structure and content of Russian universities' courses on different platforms, and classified undergraduate students' and universities teachers' questions and comments on the advantages and the drawbacks of the technical support of distance learning (see Tables 2, 3), and their perception of the distance format in comparison with the traditional one.Mathematical methods of counting the feedbacks of DLS users, 3206 students, and 437 teachers, left in DLS 
systems comments, allowed us to study the main perspectives in the development of DLS in teaching students in Economics.

Distance educational technologies are implemented mainly with the use of information and telecommunications networks with indirect (at a distance) interaction of students and teachers in accordance with the Federal Law "On Education in the Russian Federation" (2012).

To investigate the specific experienceof Economics organizing distance education in Russia, we obtained quantitative and qualitative data on all online Economics courses. We used the list of universities offering distance education from the web sites of universities and the official website of the Ministry of Science and Higher Education (2018). The site presents the educational programs in eight universities, including a variety of technological teaching methods, the best state universities in Russia, indicating state-financed openings and links to the web pages of educational programs in DLS systems of universities. We also used the list of fifty-six universities delivering distance Economics education from the catalog of universities, specialties, professions, materials on the theme of higher education (Vuzopedia, 2012).

Another source of data is twenty-four leading Russian universities' e-platforms, corporations' MOOCs for both online and blended learning in Economics Program. We combined and summarized the data and analyzed the most common DLS in Russian HEIs (universities could change the choice of DLS or new universities could establish distance education by the time of publication). Most of them are applied globally, therefore, data on foreign universities' Economics courses and their fees were additionally observed. Moodle is the main one widely used in the world. $62 \%$ of Russian universities use it, therefore it is the first among the analysed in this paper; users apply this software in 232 countries worldwide (Moodle, 2018).

\section{Results}

\section{Factors of Choice and Features of Economic Distance Learning in Russia}

Researchers often study what motivates students to choose this method (trends and goals). However, students also have objective reasons for forming their motivations. A glance at the presentation of universities concentration on the map shows that Russian HEIs concentrate in scientific, technical and educational centers of state's large territory (All Russian HEIs, 2018). In the northern and eastern regions, the concentration of universities is the lowest, in contrast to the central part. This means that apart from the territorial problem common to the world practice (the number of foreign online students grows in Western universities), DLS helps to remove the problem of dependence on severe climatic conditions with the help of the blended and distance learning. For example, in Yakutia (SAHA Republic), where due to severe frosts, it is necessary to cancel many 
activities. Even if the student lives in temperate latitudes, then to get to the university in winter during a storm from his or her native city to a metropolis, and then through traffic jams to a university located in this megalopolis, is quite problematic, especially if he or she did not cross such distances on a regular basis. DLS with the possibility of asynchronous communication unite learners located in several time zones.

After the USSR and its system of free education collapse, state financing of higher education in Russia is steadily declining. The state-financed openings in Economics - 5,219 in 2017, calculated by the authors based on the materials of HSE (2017c) and Management less than in health care more than twice, and compared to the natural sciences it declined four times. 162 Russian HEIs out of 302 do not provide state-financed openings for Economics programs (HSE, 2017c). 291 HEIs provide paid education. In 2017, they accepted 25,359 students (calculated by the authors on materials of HSE 2017b), which is about five times more than the state-financed ones.

Therefore, an important factor in the rapid development of distance education in Russia may be the relatively low cost of this form of education in relation to traditional full-time and external degree programs and distance learning abroad. According to the data gathered in Table 1, the average cost of distance education in Economics Program at Russian universities varies between $\$ 500$ and $\$ 1,000$ per year.

Table 1

The Cost of Distance Education in Economics Program at the Leading Russian Universities and Abroad (per year, 2017)

\begin{tabular}{lc}
\hline \multicolumn{1}{c}{ University } & Cost, USD \\
\hline Montreux Business University (Switzerland) & $18.104-33.894$ \\
\hline Fern University (Germany) - baccalaureate, & $2.000-2.900$ \\
magistracy & $1.200-1.500$ \\
\hline Financial University under the Government of the Russian Federation & 1.000 \\
\hline Stanford University (USA) & 19.300 \\
\hline Yale University (USA) & 20.250 \\
\hline Columbia University (USA) & 22.645 \\
\hline Universidad a Distancia de Madrid (Spain) & 5.400 \\
\hline Institute of International Trade and Law & 500 \\
\hline Moscow University of Management & 580 \\
\hline Moscow Institute of Finance and Law & 580 \\
\hline TISBI (Tatar Institute of Business Assistance) University of Management & 670 \\
\hline Tyumen Branch of the Siberian University of Consumer Cooperatives & 680 \\
\hline Chekhov Branch of the Moscow University of Finance and Law & 720 \\
\hline Vladivostok State University of Economics and Service & 740
\end{tabular}

Source: Vuzopedia 2018; FernUniversität in Hagen 2017; Smapse Education 2017; Montreux Business University 2017 
The cost of online training is taken from the official websites of universities, the British educational website and the catalog of Russian universities Vuzopedia; the price was calculated from national currencies to dollars, USD. Table 1 shows that the cost of distance learning at Russian universities is much lower than the cost of learning at universities of foreign countries. However, the relative cheapness of learning in Russia is offset by the difficulty of controlling the quality of education, and the relevance of the diploma. The relevance for diplomas in Economics depends on the international rating of the university. This may mean that the choice of economic distance education by Russian students in Russian HEIs is due to the high demand for economic education, the lower cost and using one's own language. While the remaining specialties can be limited in the use of DLS- translators and teachers of foreign languages can receive only a full-time or part-time diploma accepted at employment in educational institutions.

A number of the following factors determines the increase of distance education in Russian HEIs: the state territory and climate; the location of scientific, technical, and educational centers in big cities; the realization of the social demands in terms of the content and technology, their accessibility; distance learning increases the availability of educational services.

\section{DLS Application in Russian Economics Education}

Two groups of factors were posited to influence students' choices: personal (financial and time-saving) and objective (free education collapse, geographical concentration of universities, later informatization and legalization of distance education) (Figures 1,2).

These factors became the conceptual framework used to achieve the purpose - to explain factors (cause-effect relationship) that influenced positive and negative features of DLS application in Russian HEIs (Figure 3).

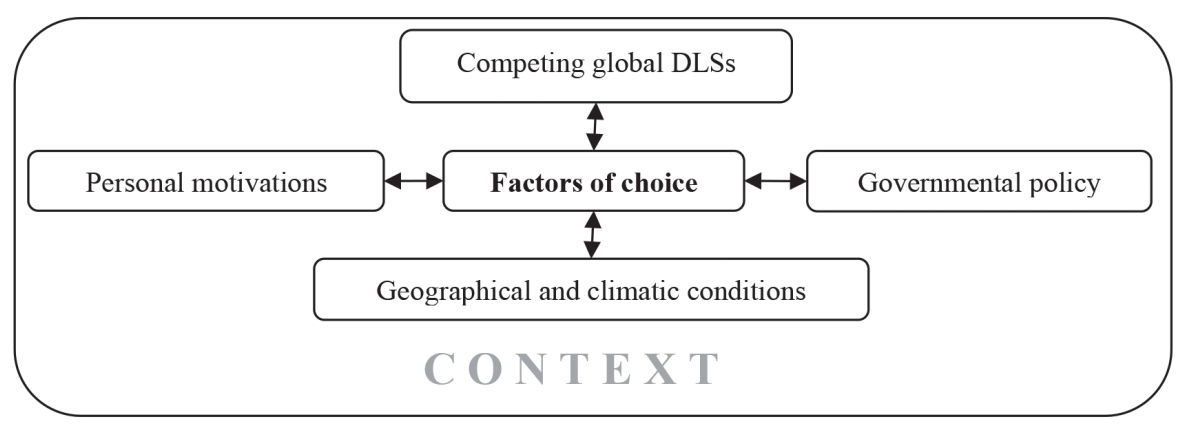

Figure 1. The Objective and Subjective Factors of Choice 


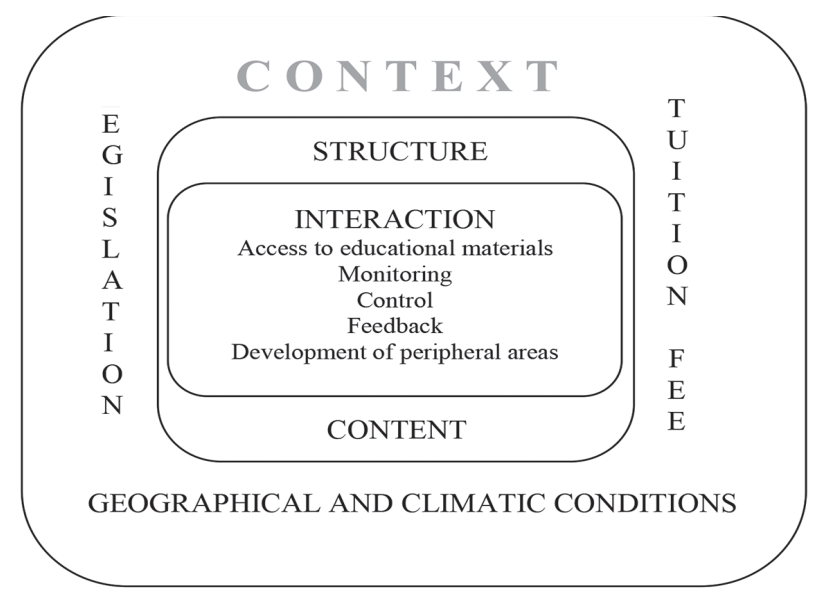

Figure 2. The Features of Russian Distance Education System

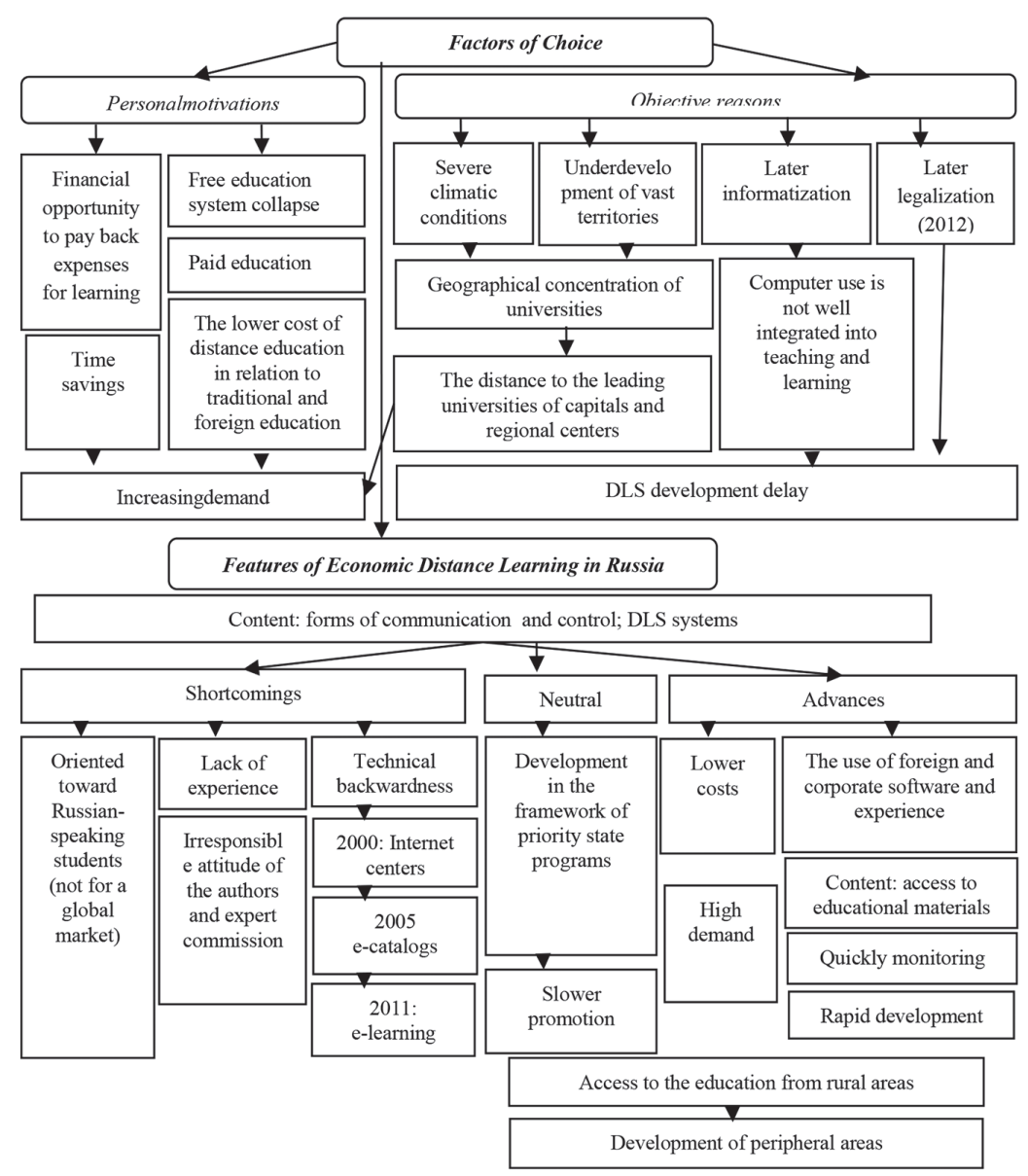

Figure 3. Factors of Choice and their Impact on the Features of distance Economics Education in Russia 
The HEIs system administrators and programmers can process platform modules, develop and configure the necessary components of interactive courses (HSE, 2018b). For independent creation of sources, teacher can use cloud sources, such as the Education Cloud (http://ooblako.ru/), and save courses in Moodle. The new free hosting for Moodle Cloud sites since 2015 allows any teacher the opportunity to organize e-learning for institutions that cannot afford to buy and support expensive equipment and software (KNITU-KAI, 2018b).

Professional training of students, specializing in economic crime counteraction, includes serving tours of police duty, periodic training with a break from classes, make-up working for any lost hours of absence, and a strict schedule like in military high schools (Voronezh Institute of the Ministry of Internal Affairs, 2018). It provides "a reduction in the time spent working on arrears for missed classes and unsatisfactory grades; increasing teaching materials availability and quality of self-training"(Kryuchkov et al. 2017, 85), which a cadet may carry out at a suitable time.

The Synergy (2018), available all over the world, was created by Moscow Financial-Industrial University. The Student DLS was ownership of Lobachevsky Novgorod State University (NSU, 2018), combining it with Moodle.

MOOCs in Russia as a new form of e-learning succeeded later than in the West. With the assistance of the government, it develops rapidly. For instance, in 2016 HSE launched over 12 educational courses subscribed by 100,000 people on Coursera platform. In HSE profileon Coursera website, eight Economics e-courses and six specialties were launched (HSE, 2018a), some of them are made in partnership with Yandex and together with Google and University of California, some are developed in English involving foreign teachers. In HSE courses on National Open Education Platform, the listeners can obtain a verified certificate after additional payment and a test, accepted by other universities. The Moscow Institute of Physics and Technology (MIPT) cooperates with Coursera; Digital October, together with Coursera, translates its courses into Russian.

St. Petersburg State University, the Russian Academy of National Economy and Public Administration under the President of Russia cooperating with Uniweb and Hexlet launched their own MOOCs. Other universities upload videos of their lectures to various media libraries, but this format is gradually losing popularity: if a student chooses between a one and a half hour video lecture and a structured convenient MOOC, then the choice will be in favor of the latter. The only example of a successful format of long video from the world's samples is TedX, but it bases on the participation of professor stars and the use of special techniques when shooting to keep the attention of viewers. While most of the videos available in Russian media libraries is an hour or more recording of a lecturer from a static camera.

Almost all Russian online learning projects providepartly paid access. This can slow the spread of popularity of regional and private MOOC-providers in the Russian segment. The exception is the Universarium (from 2013), initially positioned as a free 
MOOC-platform for Russian courses; Hexlet created and supported by enthusiasts, and Interneturok (the Russian analog of the Khan Academy). "Hybrid"platforms such as Eduson.tv (aimed initially at the BRIC countries, started in English with the help of famous teachers, mainly from the USA) and Uniweb collaborating with the faculties of Russian universities, and individual professors to distribute courses for corporate employees in an online format.The Universarium MOOC supported by the Presidential Agency for Strategic Initiatives and RIA News. The authors plan to enter the European education market: they intend to first make English subtitles and then write down the courses in English. However, there are only two courses in Economics from different universities (Coursarium, 2018).

To expand the possibilities of distance education in November 2017, the government launched "The Modern Digital Educational Environment in the Russian Federation"priority project (MDEE, 2017). Its part, Open Window Portal, operates in the pilot mode. Unlike other providers of online courses, in the interests of students and employers, it contains a developed search interface offering twenty-five courses in Economics (available on different platforms) by the leading teachers of leading universities. Its advantage is an opportunity of passing-out disciplines mastered by a student (full or partial) at the university where the student is studying; while the very opportunity to pass the estimating of knowledge is paid, in contrast to the access to educational content. The estimation system provides for a number of examinations - mandatory and several additional ones, including criteria for the effectiveness of the course, practical and public relevance, depth of study, degree of interactivity, forming the overall rating of the online course.

On the other hand, the portal receives only a small number of courses on open platforms. Thus, as of August 5, 2018, the Open Window Catalog includes 503 online courses on 18 platforms from 113 universities. Therefore, most universities find it easier, at least at this stage, to create and promote online courses for their own use. While Western projects are always led by a strong brand (EdX) or "a celebrity founder" (Coursera, Minerva Project) (e.g. HSE, 2018a), Russian projects are usually created by persons of a lesser scale (Russian universities do not rate the first lines in world rankings) or in the framework of state programs, like Prometheus (Virtual Technologies in Education, 2017), MDEE (2017), MISIS (2018), and copy Western models such as Moodle, Blackboard, Coursera. As a result, foreign projects have more chances for rapid promotion. Foreign projects themselves offer innovations - first in the design of the course (MOOC adopted in Russia), now in the work with Big Data, and in monetization models in the future.

All the reviewed sites of DLS and the Ministry of Environmental Protection contain sources to which a student can apply the required number of times and view the entire duration of studies if necessary, thereby controlling his or her educational environment without going to the library or going to university.

When studying online learning, educators continue to question whether it is effective and which course components students prefer to others. The above-mentioned analysis 
of the advantages and disadvantages of DLSs allowed us to determine the positive aspects of virtual interaction in the educational environment when receiving economic education and confirm them by a survey of all those engaged in e-education in Bashkir State University, 101 first and second-year students and twenty-four teachers (Table 2).

\section{Table 2}

\section{The Advantages and Disadvantages of Distance Education in Economics Program at Russian Universities}
Advantages
Disadvantages

Quickly monitoring the current and residual knowledge

Use DLS as a database and backup copies of materials (a kind of electronic library)

ndependently select the place and duration of classes

Effectively and flexibly use the curriculum time for activities

Remotely accept works after missed seminars and practical tasks

Organize self-training and self-learning

Access additional educational and scientific materials

Introduce active and interactive forms of education

Remotely participate in collective research on the proposed subjects

Forming the funds of estimation means for economic and accounting disciplines

Communicate with foreign teachers
Dissatisfaction of individual students with the time that passes between checking works and putting marks in the progress journals

The lesser account of oral speaking, practical tasks involving the imitation of professional communication; virtual communication does not form the so-called, "student environment", or reproduce university traditions; special psychological and pedagogical requirements for students, including their academic integrity, rigid self-discipline, independence

The need to combine tasks with direct communication

Risk of technical failures (complaints about technical failures impeding the performance of tasks)

Monetization is inherent in projects, it severely limits the potential audience and horizons of development; costs for equipment and software, the need for investments from universities

Dissatisfaction of students with the terms of checking works, lack of diversity in the forms and methods of conducting classes (lectures, consultations, tests as a control method), low interactivity of the classes)

Desire of students to perform test tasks instead of non-test ones having a higher level of complexity

Special requirements to the level of technical and methodological infrastructure

Lack of time and emotional contact. Tutors must not exceed the established schedule of hours, advise the students more than the required time using emotionally brightening up the transfer of knowledge that limits the individual approach to student counseling

Frequent attempts of academic fraud (plagiarism, replacement of a student, who performed a task; a teacher cannot control the process for its authenticity ("weak control of learning")

Issues of mutual understanding between students and teachers, caused by the usual lack of a non-verbal communication channel characteristic of "live" communication (gestures, facial expressions, non-verbal ways of communication provides making immediate corrections on the spot and ask questions) 
The identified issues of DLS in the training of undergraduate Economics were found in the archives of requests and complaints from forums, and varying degrees of the popularity of methodical materials of text and video formats (number of views, likes, and questions).

\section{Discussion}

The current paper studied recent innovations in Russian distance economic education, the first and expanded examples of DLS in Russia. We prepared it for academic economists and administration so that they could expand the boundaries of their personal experience and DLS use. However, our findings are not limited solely to the Economics Program and can be extended to other disciplines.

Most of the prior and recent research studied as follows: 1) reasons for choosing the Economics Program distance learning (Markova et al., 2017; Horspool \& Lange, 2012; Allgood et al., 2015); 2) comparison indices of online and traditional Economics students (Aljamal et al., 2015; Allgood et al., 2015; Bacolod, 2018), and 3) attitude of teachers and students to online Economics learning (Arnold, 2016; Cosgrove, 2015; Caviglia-Harris, 2016). Accordingly, in the present study, it is clarified as follows: 1) what motivates the Russian student in choosing e-learning of Economics; 2) specific features and problems of creation, presenting and use of Economics e-courses in Russia; 3) the attitudes of students and teachers to e-learning of Economics.

Study of online platforms' application including the massive open online courses in inductive economic disciplines required the processing of quantitative and qualitative data. It showed a primarily positive effect indicating the disadvantages that correlate with the recent studies and the features of the renowned online education platforms in Russia, and discusses how to use these features and correct existing disadvantages.

The present study produces results that are consistent with the previous literature and establishes new results. We have identified additional objective factors standing behind high numbers of people entering distance learning of Economics Program. In the study conducted by Markova et al. (2015), e-students did not name the cost as the most significant, however in Russia, education for young people, especially after school, is provided by parents or they help financially with housing, which could affect their answers. It also indicates that the overwhelming majority combine full-time jobs and studies, and more than half are motivated by getting an education at the place of residence, which ensures solvency.

Economic e-learning in the US is the most sought among applicants, and majors in Economics are earning significantly more than other social scientists or bachelors (Allgood et al., 2015, 293). It seems that in Russia this is the driving force for entering, as already in 2014 27.2\% of all students chose Economics specialties (HSE, 2016, 154) despite 
the lack of state-financed openings in more than half of the universities. We calculated that in 2017, each Economics state-financed student accounted for five commercial students. So, applicants are assured of an opportunity to pay back expenses for learning.

From the Western researchers' point of view, the use of DLS is beneficial to the university, since fully e-courses and blended courses of Economics free space in the classroom and potentially increase the flow of students (Cosgrove \& Olitsky, 2015; Bosshardt \& Chiang, 2018, 7). In Russia, as demonstrated in the paper, the choice of distance education is dictated by considerations of students' personalfinancial and time savings. The limitation is that the focus of Western researchers is universities' interests and financing. The present research's questionnaire contains questions on teachers' and students' attitudes.

In addition to the distance to the leading universities of capitals and regional centers, which is to some extent relevant for foreign higher education practices, DLS in Russia will help to remove the issue of dependence on severe climatic conditions. Through investing in education, young people from remote settlements try to stay and work at the place of study in central regions and cities, which creates an outflow of promising and wealthy young people from the remote area, since with a high degree of probability graduates will not return to their native cities. Hence, it is advantageous for the state to develop distance education, especially for such a large class of students as Economics students, in order to maintain and develop peripheral centers, small towns, and rural areas, facing declining populations, access to goods and services, medical and other social assistance, by supporting the work of specialists.

In the absence of such a tangible difference in the cost of learning, graphically presented in Table 1, the expansion of Economics e-courses of elite foreign universities could seriously push Russian regional universities: those who want can acquire a prestigious diploma of Stanford and Harvard without leaving home. The obstacles Russian users of foreign educational platforms may encounter are costs and lack of knowledge of English or the absence of subtitles. American and European educational projects must be initially made for the global market and international audience (for more pragmatic reasons as it is bigger). As a rule, Russian Economics e-education is oriented toward the Commonwealth of Independent States (CIS) and Russians who are abroad. Education in Russia provides large numbers of acceptance at the expense of non-residents and residing in rural areas, while the US distance education attracts international students.

However, by improving technology and filling DLS, it is possible to expand the motivation for those who prefer the traditional format of face-to-face education or postponed the graduation of Economics education.Foreign students could also widen the contingent, since in the post-Soviet space many of those who speak Russian and come to Russia for full-time study, are mostly from the CIS rather than from China, India and African countries. The prevalence of the Russian language in the post-Soviet space and the countries of the former Warsaw Pact is an indisputable reserve for the development of distance learning. This makes Russia attractive for citizens of the CIS and Eastern 
European countries. According to the experience of the US, technology and content, as well as the identified shortcomings in the use of Russian and foreign educational platforms and the results of student interviews, should be improved in the direction of increasing their convenience, interactivity, and flexibility (Horspool \& Lange, 2015), which are motifs for students of American HEIs.

The lack of schedule flexibility in students' motivations (Markova et al., 2015) is confirmed by complaints and wishes of students of Russian universities regarding technical and technological aspects of distance learning received during the research of forums and chats, issues of understanding particular tasks (Clarke, 2013), complexity of designing courses, need for training teaching staff and special software (Lock, 2015). Thus, the study confirms a need for financial and training investments from universities, psychological and pedagogical approaches to understanding individual's needs $(\mathrm{Du}, \mathrm{Xu}$ \& Fan, 2015; Kollar \& Fischer, 2014; Langan et al., 2016; Welsh, 2012; Park, 2014), adaptation to learners; and enhancing democratization of interaction and accessibility of the content (Seregina, 2018). This requires the creation of a virtual environment close to the life situation (Kultan, 2009), which can be achieved by means of gaming, and not only development of the script by teachers.

The competition of Russian universities with each other and foreign universities requires rethinking not only teachers' use specific equipment or software, but also everything they do. Students are not only concerned with the clarity and practical value of the material being taught (they have no claims to the content of the courses and highly appreciate the quality of teaching) but also the attractiveness and visibility of materials, the timely response of the teacher. As can be seen from the results, pedagogical approaches are not necessarily transformed or changed: DLS is mainly distributed by the same materials or adapted for the online format associated with the course, which previously existed in paper form and was sent by e-mail; discussions and polls are conducted in the same sequence, but more often in writing.

As for practical implications, the difference in the assessment of video content in different disciplines and prepared by different teachers, which we found, is most likely due to its quality, since the value of the educational material depends on an interesting presentation, brevity, and clarity of demonstration. Their creators are not always able to cope with the task, and from the perspective of the trainee, not all videos are an indispensable element of the learning content. The solution can be the use of videos from existing popular time-tested YouTube channels about natural and mathematical sciences. There are many useful Russian and foreign channels, but channels on Economics are fewer than necessary.

Since the main differences between traditional and distance Economics education are due to the form of transmission and acquisition of knowledge, here for the leadership of universities and the state as the main partner of universities we can offer two options of social implications. The first is teaching the complex practice of designing teachers' 
lessons, which will increase the workload or require a break from work and attracting students with their wishes and estimate before and during the introduction of courses. The second one is to attract IT and media specialists on an ongoing basis, and not just for the initial introduction of DLS and adaptation for a specific distance learning platform because the specialists already know the patterns of human perception and have the skills to create interactive and attractive material without unnecessary trial and error.

Until recently, Russian online education services for economists competed not with each other, but with traditional methods of obtaining knowledge.

The results are consistent with the recently obtained results of Aljamal et al. (2015, 38) in the Macroeconomics classes study revealed that the results of students' learning do not depend on the application of online tasks, nor on the intensity of this application, but on the controlling quality of content and instructor. Although earlier studies by Brown and Liedhold of 2002, Coates et al. of 2004, Gratton-Lavoie and Stanley of 2009, Pyne of 2007 have shown "that students in online Economics courses attained significantly lower test scores than students in regular classes"(as cited by Allgood et al., 2015, 302). This difference in results can be due to the evolution of elearning technologies, and with the teachers' mastering of presenting methods and interaction, as recognized in the case of KNITU-KAI (2018a, b).

Since results may be valid for distance education in all social and humanitarian specialties, the authors should not be limited to only the Economics Program. However, the government increases the number of state-financed openings for technical students. Students of foreign languagesdepartments know that the world and Russian online learning markets are the most developed, that is why they have a wide choice and jobs abroad, which is much more highly paid, as well as studying at prestigious universities. While the prospects and long-term effects of distance Economics education are due to high demand, standard skills of students and the orientation of most of them to work in Russian companies and own business.

Summarizing successful practices and challenges of Russian Economics distance education, we can single out the methodological principles as the basis for successful implementation of DLS: interdisciplinary, inclusion, individualization, and applying active and interactive teaching methods. The main innovative pedagogical directions, corresponding to the global experience and taking into account the Russian specificity, are technical support of users; obtaining certificates (Glavbukh, Consultant-Plus, Garant); quizzes, competitions, games; organization of supplement courses for the student's choice; external studies.

In foreign educational systems, up to $80 \%$ of students consider distance education in the future as the main form of education, devoid of subjectivity (Sutherland \& Fischer, 2014) and prefer forms of learning based on current digital technologies (Langan et al., 2016). Our results show that DLS in Russia can become the predominant form of education. The study does not take into account all risk factors and only confirms one of the 
most important trends in the national education system - the continuous growth of the share of distance educational technologies in the market.

\section{Conclusion}

The analysis of the positive and negative aspects of the virtual interaction in the educational environment in obtaining economic education has shown that the advantages of its application significantly prevail over the existing disadvantages.

The results show that due to the lower quality and technical underdevelopment of e-learning tools originally developed in Russia, Russian HEIs use mostly global e-education platforms. At the same time, the number of Russian students entering Western universities' ecourses does not increase proportionally to the total number of estudents. It also shows that the Russian Economics distance education attracts Russian contingent that is poorly acquainted with alternative foreign universities and is developing rapidly, since it does not start from scratch but uses mostly existing sites and current technologies. In addition, distance education will continue to be in demand and play a big role due to rising prices for learning, a reduction in state funding, and canceling the territorial, temporal and climatic restrictions for students living in remote areas of large educational and industrial centers of the area. An essential competitive advantage of distance education in Russia is the relatively low cost of education services in relation to the cost abroad, as well as the prevalence of the Russian language in the post-Soviet space and Eastern European countries.

At the same time, the results suggest that universities should be cognizant of adopting more techniques and ways of teaching. The main drawback of DLS for students in Economics in Russia is the unpreparedness of the creators of materials, therefore, in addition to the retraining and upgrading of teachers, it is necessary to attract professional instructors and developers of educational media and interactive sources. This is evidenced by reports of students and teachers from the sites and local regulations of the universities themselves: the students do not abandon distance education but point out the need for improving the system of student interaction with DLS and teachers.

Among the directions proposed for amendment are the following issues hampering the effective use of distance educational technologies in Russia: insufficient coordination of actions to improve the quality of e-learning, improving its regulatory, organizational, methodological and resource support; the necessity of improving current information communications.

When fulfilling these conditions, the education system will experience the application of online courses in full-time education; the increase in the number of students applying DLS and in the effectiveness of online education, and the number of Russian HEIs using DLS. 
Future research should explore what particular technical tools are needed for different Economics courses and how these tools may possibly be utilized, and compare their effectiveness.

\section{References}

Aljamal, A., Cader, H., Chiemeke, C., \& Speece, M. (2015). Empirical Assessment of E-learning on Performance in Principles of Economics.International Review of Economics Education, 18, 37-48. doi: 10.1016/j.iree.2015.02.002.

All Russian HEIs. (2018). HEIs Map. Retrieved from http://www.provuz.ru/vuz/map (Accessed on 11.03.2019.).

Allgood, S., Walstad, W. B., \& Siegfried, J. J. (2015). Research on Teaching Economics to Undergraduates.Journal of Economic Literature, 53(2), 285-325. doi: 10.1257/jel.53.2.285.

Arnold, I.J.M. (2016). Cheating at Online Formative Tests: Does it Pay Off?Internet and Higher Education, 29, 98-106. doi:10.1016/j.iheduc.2016.02.001.

Bacolod, M., Mehay, S., \& Pema, E. (2018). Who Succeeds in Distance Learning? Evidence from Quantile Panel Data Estimation.Southern Economic Journal, 84, 1129-1145. doi: 10.1002/ soej.12264.

Barankov, V. L. (2017). Legal Aspects of Using the Network, Electronic and Distance Forms of Implementing Educational Programs. Journal of Russian Law, 3, 129-137.

Bosshardt, W., and Chiang, E. P. (2018). Evaluating the Effect of Online Principles Courses on Long-term Outcomes. International Review of Economics Education, 28, 1-10. doi:10.1016/j. iree.2018.03.001.

Calafiore, P., \& Damianov, D. S. (2011). The Effect of Time Spent Online on Student Achievement in Online Economics and Finance courses. Journal of Economic Education, 42(3), 209-223. doi: $10.1080 / 00220485.2011 .581934$.

Caviglia-Harris, J. (2016). Flipping the Undergraduate Economics Classroom: Using Online Videos to Enhance Teaching and Learning. Southern Economic Journal, 83(1), 321-331. doi: $10.1002 /$ soej.12128.

Cosgrove, S. B., \& Olitsky, N. H. (2015). Knowledge Retention, Student Learning, and Blended Course Work: Evidence from Principles of Economics Courses. Southern Economic Journal, 82(2), 556-579. doi: 10.1002/soej.12045.

Coursarium. (2018). The Universarium project. Retrieved from https://universarium.org/ catalog?category=5,38 (Accessed on 28.08.2018).

Du, J., J., \& Fan, X. (2015). Help Seeking in Online Collaborative Groupwork: A Multilevel Analysis. Technology, Pedagogy and Education, 24(3), 321-337. doi: 10.1080/1475939X.2014.897962.

EdMarket research. (2017). Research of the Russian Market of Online Education and Educational Technologies. Retrieved from https://edmarket.digital. (Accessed on 27.07.2018). 
Federal Assembly of Russia. On Education in the Russian Federation, Federal Law No. 273-FZ of December 29, 2012 (as amended on July 29, 2017). Retrieved from http://pravo.gov.ru/ proxy/ips/?docbody=\&nd=102162745\&rdk=46. (Accessed on 28.11.2017).

Fern Universität in Hagen. (2018). Kosten des studiums.Retrieved from https://www.fernunihagen. de/studium/kosten/index.shtml). (Accessed on 20.06.2018).

Guri-Rosenblit, S. (2005).'Distance Education'and 'E-learning': Not the Same thing. Higher Education, 49, 467-493.

Hauge, T. E. (2014). Uptake and Use of Technology: Bridging Design for Teaching and Learning. Technology, Pedagogy and Education, 23(3), 311-323. doi: 10.1080/1475939X.2014.942750.

Horspool, A., \& Lange, C. (2012). Applying the Scholarship of Teaching and Learning: Student Perceptions, Behaviours and Success Online and Face-to-face.Assessment \& Evaluation in Higher Education, 37(1), 73-88. doi: 10.1080/02602938.2010.496532.

HSE. (2016). The Education Indices: Statistical Collection. Retrieved from https://www.hse.ru/dat a/2016/03/21/1128209800/\%D0\%98\%D0\%BD\%D0\%B4\%D0\%B8\%D0\%BA\%D0\%B0\%D1\%82 \%D0\%BE\%D1\%80\%D1\%8B\%20\%D0\%BE\%D0\%B1\%D1\%80\%D0\%B0\%D0\%B7\%D0\%BE\%D 0\%B2\%D0\%B0\%D0\%BD\%D0\%B8\%D1\%8F\%202016.pdf. (Accessed on 21.09.2018).

HSE. (2017a). Russian Online Learning Market Poised for 53 blnRoubles by 2021. Retrieved from https://www.hse.ru/en/news/edu/208978600.html. (Accessed on 23.09.2018).

HSE. (2017b). Commercial Acceptance - 2017: Average GPA of the Unified State Examination According to the Directions. HEIs Acceptance Quality Monitoring. Retrieved from https://ege. hse.ru/rating/2017/72157769/gos/?rlist=\&uplist=\&glist=Экономика\&vuz-abiturients-paidorder=ge\&vuz-abiturients-paid-val=0\&price-order=ge\&price-val=. (Accessed on 12.09.2018). HSE. (2017c). State-financed Acceptance - 2017. HEIs Acceptance Quality Monitoring. Retrieved from https:/ege.hse.ru/rating/2017/72157740/gos/?rlist=\&uplist=\&glist=Экономика\&v uz-abiturients-budget-order=ge\&vuz-abiturients-budget-val=0. (Accessed on 14.09.2018).

HSE. (2018). Courses \&Specialities. Retrieved from https://ru.coursera.org/hse (Accessed on 13.08.2018).

HSE. (2018a). Distance Learning at the Higher School of Economics.Retrieved from https://www. hse.ru/org/hse/aup/addedu/sdo. (Accessed on 14.12.2018).

KNITU-KAI. (2017, October 6). Examination of Electronic Courses of KNITU-KAI: from Alpha to Omega. Retrieved from https://kai.ru/news/new?id=6956462 (Accessed on 09.02.2019).

KNITU-KAI. (2018a). LMS Based on Blackboard Learn. Retrieved from https://bb.kai.ru:8443/. (Accessed on 20.02.2019).

KNITU-KAI. (2018b). LMS Moodle KNITU-KAI.Retrieved from https://moodle.kai.ru/.(Accessed on 20.02.2019).

Kollar, I., \& Fischer, F. (2014). Why It Is Hard To Make Use of New Learning Spaces: A Script Perspective. Technology, Pedagogy and Education, 23(1), 7-18.

Kryuchkov, V. V., Rabazanov, S. I., Lopatin, Ye. A., \& Sinelnikov, I. Yu. (2017). Opportunities of the Electronic Educational Environment 'Moodle' in the University of the Interior Ministry 
System of Russia”.Human Capital, 12, 183-187. Retrieved from https://elibrary.ru/item. asp?id=30782439. (Accessed on 31.12.2018).

Kultan, J. (2009). Zvýšenie Kvality Vzdelávania Využitím Spätnej Väzby Realizovanej Pomocou LMS. Zborník Príspevkovz Medzinárodnej Konferencie Inovačný Proces v e-Learningu. Bratislava: Ekonomická univerzita v Bratislave, 24.03.2009.

Langan, D., Schott, N., Wykes, T., Szeto, J., Kolpin, S., Lopez, C., \& Smith, N. (2016). Students'use of Personal Technologies in the University Classroom: Analyzing the Perceptions of the Digital Generation. Technology, Pedagogy and Education, 25(1), 1-17. doi: 10.1080/1475939X.2015.1120684.

Lewis, L., Farris, E., \& Alexander, D. (1997). Distance Education in Higher Education Institutions. Statistical Analysis Report.Postsecondary Education. (Report No. NCES-98-062). US Department of Education. Washington, DC: National Center for Educational Statistics.

Markova, T., Glazkova, I., \& Zaborova, E. (2017).Quality Issues of Online Distance Learning. Procedia-Social and Behavioral Sciences, 237, 685-691. doi: 10.1016/j.sbspro.2017.02.043.

Martyanova, T. (2012, July 03). Every Tenth Moskvich Has the Experience of Distance Education. Sheets, Retrieved from https://www.vedomosti.ru/management/articles/2012/07/03/kazhdyj_ desyatyj_moskvich_imeet_opyt_distancionnogo. (Accessed on 03.10.2018).

MDEE. (2017). The Course Catalog. Retrieved from https://online.edu.ru/ru/courses/?dirid=146. (Accessed on 09.08.2018.)

Ministry of Science and Higher Education of Russia. (2018). The Distance Learning in Russia. Retrieved from https://studyinrussia.ru/actual/articles/distancionnoe-obuchenie-v-rossii/, https://studyinrussia.ru/study-in-russia/programs/study_types-is-\%D0\%B4\%D0\%B8\%D1\% 81\%D1\%82\%D0\%B0\%D0\%BD\%D1\%86\%D0\%B8\%D0\%BE\%D0\%BD\%D0\%BD\%D0\%B0\%D 1\%8F/type-is-main/duration-from-0-to-100/apply/. (Accessed on 29.07.2018.).

MISIS. (2018). Center for Distance Learning. In: Distance Learning at the National Research Technological University “MISIS”. Retrieved from http://fdisto.misis.ru/disto.htm. (Accessed on 21.10.2018).

Montreux Business University. 2017. Online Programs. Retrieved from http://mbu.university/ academic-programs/online-education/online-programs/. (Accessed on 29.10.2018).

Moodle. (2018). Moodle Statistics.Retrieved from https://moodle.net/stats/. (Accessed on 11.09.2018).

NSU. (2018). The E-learning System. Retrieved from https://e-learning.unn.ru/ (Accessed on 05.09.2018).

Park, J. Y. (2014). Student Interactivity and Teacher Participation: An Application of Legitimate Peripheral Participation in Higher Education Online Learning Environments. Technology, Pedagogy and Education, 24(1), 1-18. doi: 10.1080/1475939X.2014.935743. (Accessed on 25.04.2018).

Savage, M. (2016). Mapping Pre-service Teachers'Evolving Information and Communication Technologies Pedagogy. Technology, Pedagogy and Education, 25(1), 1-22. doi: 10.1080/1475939X.2016.1148070. 
Seregina, E. (2018). The Technology of Distance Learning as a Way of Obtaining Higher Education in Russia.Perspectives of Science \& Education, 2(32), 25-29. Retrieved from https://pnojournal. files.wordpress.com/2018/04/pdf_180204.pdf (Accessed on 02.08.2018).

Smapse Education.(2017). Higher Education Abroad and in Europe. List of universities, system, cost. Educational Portal Smapse Education. Retrieved from http://smapse.com/catalog/highereducation/. (Accessed on 28.12.2017).

Sutherland, R., \& Fischer, F. (2014). Future Learning Spaces: Design, Collaboration, Knowledge, Assessment, Teachers, Technology and the Radical Past. Technology, Pedagogy and Education, 23(1), 1-5. doi: 10.1080/1475939X.2013.870107.

Synergy (2018). Official Site of the University.Retrieved from http://synergy.ru/. (Accessed 03.08.2018).

The Government of the Russian Federation. (2015). Decree of the Government of the Russian Federation No. 2765-r of December 29, 2014 "On the Concept of the Federal Target Program for the Development of Education for 2016-2020". Collection of legislation of the Russian Federation. Retrieved from http://www.pravo.gov.ru. (Accessed on 08.01.2017).

Virtual Technologies in Education, LLC. (2017). Description of the Distance Learning System "Prometheus". Retrieved from https://www.prometeus.ru/actual/03_solutions/for_vuz.html. (Accessed on 28.01.2018).

Voronezh Institute of the Ministry of Internal Affairs of Russia. (2018). The E-learning at Voronezh Institute of the Ministry of Internal Affairs of Russia. Retrieved from https://moodle.vimvd. ru/course/index.php?categoryid=8. (Accessed on 28.04.2018).

Vuzopedia. (2012). Distance Economic Institutes of Russia. In The Catalog of Universities, Specialties, Professions, Materials on the Theme of Higher Education. Retrieved from http:// vuzopedia.ru/vuzfilter?vuz $=\&$ distans $=1 \&$ price $\% 5 \mathrm{~B} \% 5 \mathrm{D}=0 \&$ price $\% 5 \mathrm{~B} \% 5 \mathrm{D}=1000000 \&$ spe ca\%5B $\% 5 \mathrm{D}=129 \&$ speca $\% 5 \mathrm{~B} \% 5 \mathrm{D}=136 \&$ speca $\% 5 \mathrm{~B} \% 5 \mathrm{D}=163 \&$ speca $\% 5 \mathrm{~B} \% 5 \mathrm{D}=272 \&$ speca $\% 5$ $\mathrm{B} \% 5 \mathrm{D}=408 \&$ speca $\% 5 \mathrm{~B} \% 5 \mathrm{D}=432 \&$ speca $\% 5 \mathrm{~B} \% 5 \mathrm{D}=443 \&$ mat $=\&$ rus $=\&$ fiz $=\&$ obshe $=\& \mathrm{ist}=\&$ biol $=\&$ inform $=\&$ him $=\&$ liter $=\&$ georg $=\& i n y a z=. ~($ Accessed on 20.05.2018).

Welsh, M. (2012). Student Perceptions of Using the Pebblepad E-portfolio System to Support Self- and Peer-based Formative Assessment. Technology, Pedagogy and Education, 21(1), 57-83. doi: 1080/1475939X/2012.659884.

Zykova, T., Shershneva, V. A., Vainshtein, Y. V., Kosmidis, I. F., \& Kytmanov, S. A. (2017). Teaching Mathematical Disciplines in Conditions of Applying Cloud Technologies on the Basis of LMS Moodle. Bulletin of the Astafiev Krasnoyarsk State Teacher Training University, 4(42), 58-65. doi: 10.25146/1995-0861-2017-42-4-21. 


\title{
Ekonomikos bakalauro studiju paskutinio kurso studentu nuotolinis profesinis mokymas Rusijoje
}

\author{
Miliausha Faritovna Sirazetdinova ${ }^{1}$, Rushana Khusainovna Lukmanova $^{2}$, Anatoliy Igorevich Stoletov ${ }^{3}$ \\ 1 Baškirijos valstybinis universitetas, Istorijos ir viešojo administravimo institutas, Mokslo ir organizavimo katedra, \\ Tukajevo g. 1 (iejjimas iš Karlo Markso g. 3/4), Pastatas 1, Ofisas 501, 450076 Ufa, Rusija \\ 2 Baškirijos valstybinis universitetas, Istorijos ir viešojo administravimo institutas, Užsienio istorijos katedra, \\ Tukajevo g. 1 (įejimas iš Karlo Markso g. 3/4), Pastatas 1, Ofisas 519, 450076 Ufa, Rusija \\ 3 Baškirijos žemės ūkio valstybinis universitetas, Žemės ūkio technologijų ir miškininkystės fakultetas, Socio- \\ ekonominių dalykų ir humanitarinių mokslų katedra, 50 let Oktiabria g. 34, Ofisas 356/1, 450015 Ufa, Rusija
}

\section{Santrauka}

Nuotolinis ekonomikos mokymas pirmiausia buvo išvystytas ir išplètotas Rusijoje, ir autoriai, siekdami atsakyti ị iškilusius klausimus, ištyrè šio mokymo sẻkmę. Tyrimo tikslas - apibrèžti veiksnius, kurie kartu su bendrojo nuotolinio švietimo gerinimu skatina ekonomikos mokymą, lyginant jị su kitomis specialybėmis, ir nustatyti šių veiksnių ypatybes trūkumams pašalinti. Keliama hipotezė, kad Rusijoje ekonomikos nuotolinio mokymo ypatumus nulèmé didelè ekonomikos kursų paklausa ir praktikų techninis atsilikimas nuo kitų pasaulio šalių. Tyrime analizuojami nuotolinio mokymo pranašumai ir trūkumai. Ši analizè apima studentų atsiliepimus, lyginamos įvairios e- mokymosi priemonès, kurias taiko Rusijos universitetai. Mes išanalizavome kiekvieną platformą ir pateikème jos komentarus, norėdami atskleisti bendrus bruožus.

Tai yra pirmasis straipsnis, kuriame dèmesys sutelkiamas į istoriją ir socialinius bei ekonominius veiksnius (išlaidas, geografines sąlygas ir politinę pertvarką, globaliąsias IT), kurie paveikè ekonominio mokymo vystymąsi. Tyrimo vientisumas ir išsamumas grindžiamas konceptualiu pagrindu. Noredami patvirtinti / įrodyti tyrimo rezultatus, mes atkreipème dèmesị i ypatybes ir tendencijas ir pateikème skirtingų nuotolinio mokymosi sistemų ( DSL) pranašumų ir trūkumų pavyzdžių, palyginome nuotolinio mokymosi svetaines Rusijoje ir sutelkème dèmesị i jų metodus dèstydami ekonomikos programą. Straipsnis prisideda prie konkretaus žinių sektoriaus ir gali būti naudingas būsimų tyrimų pagrindas.

Esminiai žodžiai: elektronine švietimo aplinka, profesinis mokymas, švietimo standartai, MOOC (atviri visuotinio internetinio mokymo kursai), nuotolinio mokymosi sistemos (DSL).

Gauta 20190313 / Received 13032019

Priimta 20190916 / Accepted 16092019 